\title{
Analysis of Anterior Trunk Symmetry Index (ATSI) in healthy school children based on 2D digital photography: normal limits for age 7-10 years
}

\author{
Lukasz Stolinski*, Dariusz Czaprowski, Mateusz Kozinoga, Krzysztof Korbel, Piotr Janusz, Marcin Tyrakowski, \\ Katsuki Kono, Nobumasa Suzuki, Tomasz Kotwicki
}

From 10th International Conference on Conservative Management of Spinal Deformities - SOSORT 2013

Annual Meeting

Chicago, IL, USA. 8-11 May 2013

\section{Background}

Digital photography for a 2-dimensional assessment of the body shape is a valuable method to both document the human posture and calculate the main quantitative parameters of it.

\section{Purpose}

The goal of this study was to assess the frontal plane symmetry of the anterior trunk in healthy school children based on the digital photography by measurement of the Anterior Trunk Symmetry Index (ATSI). .

\section{Methods}

The study comprised 421 school children, both sexes, aged 7-10 years, with no clinical evidence of scoliosis (Angle of Trunk Rotation $<5^{\circ}$ ). One frontal photograph of anterior trunk in spontaneous standing position was taken with a digital camera in standardized manner. The semi-automatic software for calculation of photogrammetric parameters was developed in collaboration with an IT specialist. The photographs were analyzed to obtain a quantitative assessment of the ATSI parameter. The intra-observer error was calculated by the first author by measuring the pictures of 14 children three times, selected randomly, at the interval of at least two days. The inter-observer error was calculated by one surgeon and two experienced physiotherapists by measuring the pictures of 60 children, selected randomly. The normal upper value limit was calculated as mean $+2 \mathrm{SD}$.

\section{Results}

The mean ATSI value for 421 children was $24.3 . \pm 12.7$

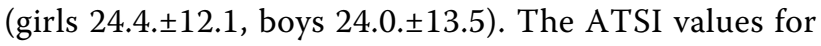
each age group were: (1) 7-year-old children $(\mathrm{N}=117)$ : $26.0 \pm 12.9$ (girls $25.9 \pm 12.5$, boys $26.2 \pm 13.4$ ); (2) 8-yearold children ( $\mathrm{N}=85$ ) $23.3 \pm 13.7$ (girls $23.0 \pm 12.2$, boys 23.7 \pm 16.1 ); (3) 9-year-old children $(\mathrm{N}=109) 24.5 \pm 12.7$ (girls $23.9 \pm 11.9$, boys $26.1 \pm 14.1$ ); and (4) 10 -year-old children $(\mathrm{N}=110) 22.9 \pm 11.7$ (girls $24.5 \pm 11.6$, boys $21.8 \pm 11.5$ ). For all age groups, the mean ATSI for boys did not differ significantly from the mean ATSI for girls $(\mathrm{P}>0.05)$. For both boys and girls, the mean ATSI did not differ among the four age groups $(\mathrm{P}>0.05)$. The intra-observer error was 1.07. The inter-observer error for the three observers was 4.06. The upper value limit was: (1) for 7-year-old children: girls $=50.9$ and boys $=53.0$; (2) for 8-year-old children: girls $=47.4$ and boys $=55.9$; (3) for 9 -year-old children: girls $=49.9$ and boys $=47.7$; and (4) for 10-year-old children: girls $=47.7$ and boys $=44.8$.

\section{Conclusions and discussion}

Using semi-automatic software, the ATSI parameter could easily be calculated on regular digital photographs. The mean value of ATSI did not differ between boys and girls for the age group range of 7-10 years. Clinical usefulness of the ATSI parameter is yet to be determined by undertaking studies on larger groups of healthy and scoliotic children at different ages.

Published: 18 September 2013

\footnotetext{
* Correspondence: stolinskilukasz@op.pl
}

Rehasport Clinic, Poznań, Poland

( 2013 Stolinski et al; licensee BioMed Central Ltd. This is an Open Access article distributed under the terms of the Creative Commons Attribution License (http://creativecommons.org/licenses/by/2.0), which permits unrestricted use, distribution, and reproduction in any medium, provided the original work is properly cited. 


\section{Reference}

1. Stolinski L, Kotwicki T, Czaprowski D, Chowanska J, Suzuki N: Analysis of the Anterior Trunk Symmetry Index (ATSI). Preliminary report. Stud Health Technol Inform 2012, 176:242-246.

doi:10.1186/1748-7161-8-S2-P10

Cite this article as: Stolinski et al: Analysis of Anterior Trunk Symmetry Index (ATSI) in healthy school children based on 2D digital photography: normal limits for age 7-10 years. Scoliosis 2013 8(Suppl 2):P10.

Submit your next manuscript to BioMed Central and take full advantage of:

- Convenient online submission

- Thorough peer review

- No space constraints or color figure charges

- Immediate publication on acceptance

- Inclusion in PubMed, CAS, Scopus and Google Scholar

- Research which is freely available for redistribution

Submit your manuscript at www.biomedcentral.com/submit 